\title{
The Effect of Fermented Dragon Fruit Peels Juice Provision in Drinking Water on Weight of 6-14 Week Old Quail's Carcass
}

\author{
Made Pravdivna Fera Stradivari ${ }^{1, *}$, Gusti Ayu Mayani Kristina Dewi ${ }^{2}$, I Made Nuriyasa ${ }^{3}$ \\ ${ }^{1}$ Postgraduate, Faculty of Animal Science, Udayana University, Indonesia. \\ ${ }^{2}$ Poultry Science Laboratory, Faculty of Animal Science, Udayana University, Indonesia. \\ ${ }^{3}$ Anatomy and Physiology Laboratory, Faculty of Animal Science, Udayana University, Indonesia.
}

How to cite this paper: Made Pravdivna Fera Stradivari, Gusti Ayu Mayani Kristina Dewi, I Made Nuriyasa. (2021) The Effect of Fermented Dragon Fruit Peels Juice Provision in Drinking Water on Weight of 6-14 Week Old Quail's Carcass. International Journal of Food Science and Agriculture, 5(3), 389-392.

DOI: $10.26855 /$ ijfsa.2021.09.008

Received: May 26, 2021

Accepted: June 25, 2021

Published: July 22, 2021

*Corresponding author: Made Pravdivna Fera Stradivari, Postgraduate, Faculty of Animal Science, Udayana University, Indonesia.

Email: madep.ferastradivari@gmail.com

\begin{abstract}
The present research aims to studied the parts weight of quail's carcass which are given the fermented dragon fruit peels juice (Hylocereus $s p$ ), which was conducted for 8 weeks. This research used Completely Randomized Design (CRD) which has 5 treatments and 4 repetitions in every unit consists of 10 quails, so it is totally 200 quails 6 weeks old. The treatments conducted were $\mathrm{A}=$ Drinking water without dragon fruit peels juice; $\mathrm{B}=$ Drinking water with $1 \%$ of dragon fruit peels juice, $\mathrm{C}=$ Drinking water with $1 \%$ of fermented dragon fruit peels juice; $\mathrm{D}=$ Drinking water with $3 \%$ of dragon fruit peels juice, $\mathrm{E}=$ Drinking water with 3\% of fermented dragon fruit peels juice. The variables observed in this research were the weight of the carcass part which consisted of the weight of the breast, back, thigh, drumstick, and wing. The result of this research proved that (A) the weight of carcass part which included the weight of the breast, back, thigh, drumstick, and wing with the drinking water added with $1 \%$ of dragon fruit peels juice; (B) the treatment of drinking water added with 3\% of dragon fruit peels juice; (D) the treatment of drinking water added with $1 \%$ fermented dragon fruit peels juice; (C) and the drinking water added with $3 \%$ of fermented dragon fruit peels juice; $(E)$ influenced significantly $(P<0.05)$ from the drinking water treatment without the dragon fruit peels (A). Based on the result, it can be concluded that the weight of carcass part given with drinking water added with dragon fruit peels juice $1 \%$ and $3 \%$ and drinking water added with fermented dragon fruit peels juice $1 \%$ and $3 \%$ influenced significantly towards the weight of the breast, back, thigh, drumstick, and wing compared to the drinking water without dragon fruit peels juice.
\end{abstract}

\section{Keywords}

Quails, Dragon Fruit Peels Juice, Fermented Dragon Fruit Peels Juice, Part of the Carcass

\section{Introduction}

Quail livestock is very potential to be developed and taken for its eggs and meat production. Among all the types of laying fowl, quail is the second-biggest egg producer after the laying pullet. Besides its egg production, quail's meat also has great taste, savory, and soft textured. Quail has a small body, faster growth in body and maturity of its sex, high eggs production, short period of interval generation, and fast incubation period [1]. The feed nutrition that can support the quail's life needs can affect its production.

High feed efficiency can be accomplished if the metabolism of the quail is in an optimal condition which means that 
it can operate sufficiently in absorbing feed's nutrition. A lot of ways can be done to improve feed efficiency without influencing badly towards productivity. One of the ways is to use the fermented dragon fruit peels juice in the drinking water.

Therefore, breeders often give additives by mixing in the ration or the drinking water. One alternative substance [2] shows that the dragon fruit peels juice can be given maximumly at the level $1 \%$, yet, [3] the dragon fruit peels can be given as much as $4 \%$ on the additive quail which can be given on the quail is the red dragon fruit peels (Hylocereus polyrhizus).

The effort in improving the nutrient values of the dragon fruit peels can be conducted using fermented technology in making use of Saccharomyces cerevisiae. Saccharomyces cerevisiae is used as a fermenter because its growth is quick and easy, plus it does not produce mycotoxins so that it is not dangerous [4].

Based on the description, research is urgently needed to improve the use-value of dragon fruit peels by fermenting it using Saccharomyces cerevisiae as the additional additive given to the quail to improve the carcass production.

\section{Materials and methods}

\subsection{Research design}

The research design used in the present research is Completely Randomized Design (CRD) which consists of five treatments and four repetitions. The treatments were based on the dragon yeast and tape fermented fruit peels juice level of use (Saccharomyces cerevisiae). Each unit of treatment uses 10 quails ages of 6 until 14 weeks thus generally use 200 quails. The treatments given were:

A = Drinking water without dragon fruit peels juice

$\mathrm{B}=$ Drinking water with $1 \%$ of dragon fruit peels juice

$\mathrm{C}=$ Drinking water with $1 \%$ of fermented dragon fruit peels juice

$\mathrm{D}=$ Drinking water with $3 \%$ dragon fruit peels juice

$\mathrm{E}=$ Drinking water with $3 \%$ fermented dragon fruit peels juice

\subsection{Setting and time of research}

The research was carried out in Desa Penarungan, Badung, Bali, Indonesia, with 12 weeks of time allocation (2 weeks of preparation, 8 weeks of data collection, and 2 weeks of data analysis). The preparation phase of research was conducted with the internal coordination activity, research setting preparation, infrastructure, livestock preparation, and feed adaptation.

\subsection{Diets and drinking water}

Diets is used in this research was QQ 504 S PT. Sierad Produce Tbk. Drinking water is given ad libitum. While the provision of rations is carried out twice a day, in the morning and evening. The drinking water provided is water with a mixture of dragon fruit peels juice and fermented dragon fruit juice at the level of $1 \%$ and $3 \%$.

The processing of dragon fruit peels juice is done by first setting up a dragon fruit peels in small pieces and made the fermentation process. After fermented the dragon fruit peels then blend with water until smooth.

\subsection{Variables}

The variables observed were the weight of the carcass part including the weight of the breast, back, thigh, drumstick, and wing.

\subsection{Data analysis}

The data result was analyzed using a variance. If the results are significantly different $(\mathrm{P}<0.05)$ followed by Duncan's Multiple Distance Test (Steel dan Torrie, 1993).

\section{Results and discussion}

The result of this research showed a real difference of results $(\mathrm{P}<0.05)$. Based on the research on the weight of back, thigh, drumstick, and wing, quails which were given drinking water only treatment (A) showed the lowest weight and the highest was from the quails that were given drinking water with $1 \%$ of fermented dragon fruit peels juice (C) and the treatment of drinking water with $3 \%$ of fermented dragon fruit peels juice $(E)$.

Based on statistical analysis, the provision of $1 \%$ fermented dragon fruit peel juice (C) and $3 \%$ fermented dragon fruit peel juice $(E)$ of fermented dragon fruit peels real $(\mathrm{P}<0.05)$ can be increase the final body weight compored with control treatment (A) and same with treatment with dragon fruit peels juice 1\% (B) and treatment with dragon fruit peels juice $3 \%$ (D). The final body weight is affected by the amount of feed consumed and the nutrient content absorbed by the 
body will provide higher final body weight because it will increase the development of tissue in the body livestock [6].

Table 1. Productivity of Quail’s 6-14 Week Old Carcass with Drinking Water Fermented Dragon Fruit Peels Juice Provision

\begin{tabular}{|c|c|c|c|c|c|c|}
\hline \multirow{2}{*}{ Variables } & \multicolumn{5}{|c|}{ Treatments $^{1)}$} & \multirow{2}{*}{ SEM $^{2}$} \\
\hline & A & $\mathbf{B}$ & C & D & $\mathbf{E}$ & \\
\hline The final body weight (g) & $161^{\mathrm{a}}$ & $161^{\mathrm{b}}$ & $165^{\mathrm{c}}$ & $162^{\mathrm{b}}$ & $168^{\mathrm{c}}$ & 1.21 \\
\hline Carcass weight (g) & $77.45^{\mathrm{a}}$ & $96.34^{\mathrm{a}}$ & $113.1^{\mathrm{c}}$ & $99.18^{\mathrm{b}}$ & $109.2^{c}$ & 1.23 \\
\hline Carcass (\%) & $48.10^{\mathrm{a}}$ & $59.83^{b}$ & $68.54^{\mathrm{c}}$ & $61.22^{\mathrm{b}}$ & $66.18^{\mathrm{c}}$ & 1.21 \\
\hline Breast Weight (g) & $31.34^{\mathrm{a}}$ & $41.55^{\mathrm{b}}$ & $47.65^{\mathrm{b} 3)}$ & $42,51^{\mathrm{b}}$ & $42.60^{\mathrm{b}}$ & 1.51 \\
\hline Back Weight (g) & $17.31^{\mathrm{a}}$ & $21.01^{\mathrm{b}}$ & $30.09^{c}$ & $23.95^{\mathrm{b}}$ & $29.01^{\mathrm{c}}$ & 1.31 \\
\hline Thigh Weight (g) & $11.29^{\mathrm{a}}$ & $14.41^{\mathrm{b}}$ & $14.24^{\mathrm{c}}$ & $13.10^{\mathrm{b}}$ & $15.80^{\mathrm{C}}$ & 0.45 \\
\hline Drumstick Weight (g) & $8.94^{\mathrm{a}}$ & $9.75^{\mathrm{a}}$ & $11.25^{\mathrm{c}}$ & $10.05^{\mathrm{b}}$ & $11.22^{\mathrm{C}}$ & 0.26 \\
\hline Wing Weight (g) & $8.57^{\mathrm{a}}$ & $9.62^{\mathrm{b}}$ & $9.87^{\mathrm{c}}$ & $9.57^{\mathrm{b}}$ & $10.57^{\mathrm{C}}$ & 0.18 \\
\hline
\end{tabular}

Information:

1) The values of the same superscript on the same row show the unreal differences $(\mathrm{P}>0.05)$.

2) $\quad A=$ Drinking water without dragon fruit peels juice

$\mathrm{B}=$ Drinking water with $1 \%$ of dragon fruit peels juice

$\mathrm{C}=$ Drinking water with $1 \%$ of fermented dragon fruit peels juice

$\mathrm{D}=$ Drinking water with 3\% dragon fruit peels juice

$\mathrm{E}=$ Drinking water with $3 \%$ fermented dragon fruit peels juice

3) SEM: Standard Error of The Treatment Means

The weight of a carcass is determined by the size of the outer body parts, such as the head, neck, innards, feathers, and blood. The height of the carcass part of the quail on the treatments $\mathrm{C}$ and $\mathrm{E}$ are caused by the antioxidant content in the dragon fruit peels which is also relatively high. According to the study carried out towards the content of total phenolic, and antioxidant activity, and antiproliferative activity, the peels of the dragon fruit is a stronger inhibitor for cancer growth compared to the non-toxic meat. A super red dragon fruit peels extract (Hylocereus costaricensis) with the water solvent consisting of $1.1 \mathrm{mg} / 100 \mathrm{ml}$ anthocyanin [6].

The results of the study show, that the weight of the carcass in treatment A, C and E shows A different real result $(\mathrm{P}<0.05)$. It is suspected because the effectiveness of the compounds contained in the dragon fruit peel as an antioxidant, antiseptic, natural and antibacterial antibiotic, causing maximum nutrient absorption will cause the efficiency of the ration also maximal so that it will affect the weight of carcasses.

States that the percentage of carcasses is closely related to weight loss and weight gain [7]. It is also likely to cause because the fodder used in this study has the same protein and energy balance. Energy is required for all life activities and the production of meat so that lack of energy can lead to stunted growth [8].

Besides that, the presence of Saccharomyces cerevisiae as the fermenter can help to improve the digestibility of the ration, where the improvement can increase the intake of the local breed chicken. This is in line with that the use of Saccharomyces cerevisiae which is contained in the yeast can improve the digestion process of the fibrous feed in the poultry [9].

As the probiotic, Saccharomyces cerevisiae can help to reduce the presence of microorganism pathogens in the digestive tract, thus can help to improve the health of the quail itself.

On treatment E, it shows that the weight of the higher carcass part which is the given water drink is added with fermented dragon fruit peels juice $S$. cerevisiae with the higher level, thus, it can improve the quail digestion tract health. This can help the nutrients' absorption become better. As a result, the nutrition substance such as fat, protein, and carbohydrate which are usually wasted in the feces becomes fewer. This is supported by the improvement of the weight of the quail and improved the weight of the quail carcass part.

\section{Conclusions}

Based on the result, it can be concluded that the weight of carcass part given with drinking water added with dragon fruit peels juice $1 \%$ and $3 \%$ and drinking water added with fermented dragon fruit peels juice $1 \%$ and $3 \%$ influenced significantly towards the weight of the breast, back, thigh, drumstick, and wing compared to the drinking water without dragon fruit peels juice.

\section{Acknowledgement}

I would like to thank to Rector Udayana University, Director of Pascasarjana Udayana University, Chairman of 
Animal Science Program Study of Pascasarjana Udayana University, Dean of Faculty of Animal Science, Poultry Science Laboratory, Faculty of Animal Sience, Udayana University and Anatomy and Physiology Laboratory, Faculty of Animal Science, Udayana University for their administration service and education facilities to the author.

\section{References}

[1] M. Khalil. (2015). “Use of Enzymes to Improve Feed Conversion Efficiency in Japanese Quail Fed a Lupin-based Diet.” Thesis. The University of Western Australia, 2015.

[2] A. S. E. W. Mustika. (2014). "Pengaruh Penambahan Tepung Kulit Buah Naga Merah (Hylocereus Polyrhyzus) dalam Pakan terhadap Performan Produksi Burung Puyuh (Coturnix Japonica),” Skripsi. Universitas Brawijaya Malang, 2014.

[3] R. A. M. A. M. I. G. P. R. W. D. Y. P. Rosa. (2013). "Suplemen Pakan Berbasis Limbah Kulit Buah Naga (Hylocereus undatus) Guna Menghasilkan Telur Puyuh Yang Kaya Vitamin A dan Rendah Kolesterol.” Institut Pertanian Bogor, 2013.

[4] K. K. K. a. S. J. P. Ratanapadhit. (2010). "Potential of glucoamylase and cellulose production using a mixed culture of Aspergillus niger TISTR 3254 and Trchoderma resei TISTR 3081.” KKU. Res. J., 15(9), p. 2553, 2010.

[5] G. K. R. I. N. M. L. I. M. W. d. N. M. D. Dewi. (2013). "Pengaruh Energi Protein Ransum terhadap Karkas dan Organ Dalam Ayam Kampung Umur 35 Minggu.” Prosiding Seminar nasional II Himpunan Ilmuan Pakan Indonesia (HITPI), p. 285288, 2013.

[6] Ariesta, A. H., I. G. Mahardika dan G. A. M. K. Dewi. (2015). Pengaruh level energi dan protein ransum terhadap penampilan ayam buras umur 0-10 minggu. MIP. Fakultas Peternakan. Universitas Udayana. Denpasar.

[7] E. A. Saati. (2009). "Identifikasi Dan Uji Kualitas Pigmen Kulit Buah Naga Merah (Hylocareus costaricensis) Pada Beberapa Umur Simpan Dengan Perbedaan Jenis Pelarut.” Direktorat Penelitian dan Pengabdian Masyarakat JIPTUMMDPPM. Malang. UMM, 2009.

[8] Lodang, E. M. F. R., Dewi, G. A. M. K., and Nuriyasa, I. M. (2020). “The effect of giving betel leaf extract (piper betel 1.) on the production and quality of broiler carcasses.” International Journal of Life Sciences, 4(1), 19-25.

[9] R. Ahmad. (2005). "Pemanfaatan Khamir Sccharomyces cerevisiae.” Wartazoa, 15(1), pp. 49-55, 2005.

[10] Mardewi, N. K., Astiti, N. M. A. G. R., Rukmini, N. K. S., Rejeki, I. G. A. D. S., Tonga, Y., and Suwitari, N. K. E. (2017). "Supplementation of moringa (moringa oliefera) powder into ration in increasing the quality of broiler's meat." International Research Journal of Engineering, IT \& Scientific Research, 3(3), 31-44. 